Portuges, Catherine. "Kékesi, Zoltán. 2015. Agents of Liberation - Holocaust Memory in Contemporary Art and Documentary Film. Trans. Reuben Fowlkes. Budapest and New York: Central European University Press; Saint Helena, CA: Helena History Press. 221 pages." Hungarian Cultural Studies. e-Journal of the American Hungarian Educators Association, Volume 11 (2018) DOI: 10.5195/ahea.2018.342

\title{
Kékesi, Zoltán. 2015. Agents of Liberation - Holocaust Memory in Contemporary Art and Documentary Film. Trans. Reuben Fowlkes. Budapest and New York: Central European University Press; Saint Helena, CA: Helena History Press. 221 pages.
}

\author{
Reviewed by Catherine Portuges*, University of Massachusetts, Amherst
}

In this powerful volume, Agents of Liberation: Holocaust Memory in Contemporary Art and Documentary Film, the Hungarian-born scholar and researcher Zoltán Kékesi examines selected artworks produced over the past three decades that transform or reframe social memory of the Shoah. Contextualized by a global landscape of transdisciplinary and intermedial production, the project provides historical, cultural and political perspectives on artists engaged in critical creative activity, with particular attention to the geographical regions of Eastern Europe, Germany and Israel. Deploying a dialectical approach performed through a comparative methodological lens, the author proposes case studies that enable him to analyze connections and differences between fiction and documentary, testimony and archive, oral history and interpretive art. It is important to note that Chapters 1-9 were originally published in a Hungarian edition under the title Haladék: Holokauszt emlékezet a kortárs mü vészetben ['Respite: Holocaust Memory in Contemporary Art'] (Budapest: Kijárat Kiadó, 2011). While the Hungarian term haladék (respite, reprieve, moratorium) might suggest a temporary hiatus before prior action is resumed, it is the title of Chapter 10 in the present English translation, "Agents of Liberation," that is also deployed as the title of this entire volume, thereby imparting an active and indeed activist tonality to this study of pertinent interest to the fields of Hungarian Studies, Holocaust studies, film studies, and art history, as well as for the general reader. The use of the word "Agents" anticipates the theme of agency that lies at the heart of this endeavor investigating what the author calls the "three central maintainers and mediums of Holocaust memory... the testimony of the survivors, the topography of the genocide and the archive..." (1).

The author's scholarly trajectory qualifies him well for such a challenging study: a Budapest native, Zoltán Kékesi earned his $\mathrm{PhD}$ in Comparative Literature and Cultural Studies from Eötvös Loránd University, Budapest, and since 2009 he has been a faculty member in the Department of Art Theory and Curatorial Studies at Budapest University of Fine Arts, during which time he was also guest lecturer and research fellow at Humboldt University, Berlin, the University of Vienna, the Center for Jewish History, New York, and the Mandel Center for Advanced Holocaust Studies, United States Holocaust Memorial Museum, Washington D.C.

*portuges@complit.umass.edu

(cc) $\mathrm{Br}$

ULIS D-Serle
New articles in this journal are licensed under a Creative Commons Attribution 4.0 International License.

This journal is published by the University Library System of the University of Pittsburgh as part of its D-Scribe Digital Publishing Program and is cosponsored by the University of Pittsburgh Press 
Portuges, Catherine. "Kékesi, Zoltán. 2015. Agents of Liberation - Holocaust Memory in Contemporary Art and Documentary Film. Trans. Reuben Fowlkes. Budapest and New York: Central European University Press; Saint Helena, CA: Helena History Press. 221 pages." Hungarian Cultural Studies. e-Journal of the American Hungarian Educators Association, Volume 11 (2018) DOI: 10.5195/ahea.2018.342

His current research investigates the visual and cultural history of modern anti-Semitism and the radical right with a focus on Central and Eastern Europe.

Kékesi structures his exploration of Holocaust representation in contemporary international documentary cinema and artistic practice in three parts: Part I: "The Politics of Testimony," gesturing toward the canonical representational paradigm that has dominated Holocaust discourse since the 1980s (and whose eminent theorist, Shoshana Felman, has postulated that testimony is not simply what we think we know it is); Part II: "The Archive (in Spite of All)," referencing Georges Didi-Huberman's Images in Spite of All: Four Photographs from Auschwitz/Images malgré tout (2008/2004); and Part III: "Site and Speech," evoking the original sub-title of Claude Lanzmann's magisterial oeuvre, Shoah: Le site et la parole. Shoah, in Kékesi's words, consists of "interviews made with survivors, eye-witnesses and perpetrators, along with contemporary footage of the 'non-sites' of the trauma, the former scenes of the genocides" (5); Lanzmann rigorously excluded any archive images of the camps, the deportations, or the ghettoes, a stance Kékesi considers "dogmatic," in contrast to, say, Alain Resnais's 1955 documentary, Night and Fog/Nuit et Brouillard .

Informed by the philosophical stances of Agamben and Foucault, Kékesi devotes each case study to the inscription of a distinct and independent set of artistic genres or forms that consider recent works created in dialogue with earlier cinematic texts of Holocaust history, thus juxtaposing narrative fiction and personal memory. Both Chapter 1, "The Reappropriation of Violence: The Speech of the Resistance Fighters/Claude Lanzmann: Shoah (1985) and Sobibór, 14 October 1943, 4pm," and Chapter 2, "The Restoration of Difference: The Speech of the Perpetrator/Claude Lanzmann: Shoah (1985)," concern positions proposed and performed by Lanzmann with regard to the limits of Holocaust representation that remain central to current ethical debates. "The Melancholy of the Archive" (Chapter 3) sets the stage for investigating recent art installations in relation to 1980 s experimental collages by practitioners such as the eminent Hungarian media artist and filmmaker Péter Forgács. In Respite (2007), which is discussed in Chapter 4, "The Afterlife of Images," Haroun Farocki reappropriates a silent montage of shots made in spring 1944 by the Jewish deportee Rudolph Breslauer in the Westerbork transit camp on the orders of SS Commander Albert Gemmeker, ostensibly for the camp's "documentation and graphics" section. The original footage is given a different meaning in the sixty-three year interval between the original production and the contemporary film, thus allowing for a different understanding of genocide. A similar move is made in Chapter 5, "Mediating the Perpetrator's Speech/Romuald Karmakar: The Himmler Project (2000)," by the neutral tone in which an actor reads Reichsführer-SS Heinrich Himmler's Posen/Poznaň Speech delivered to SS generals in October 1943, thereby enabling the viewer to "hear" the archive.

Based on a montage of sequences of archive sound and film image made during the Eichmann trial in Jerusalem in 1961, Chapter 6, "In the Leading Role: Adolf Eichmann/Eyal Sivan: The Specialist (1999)," analyzes the way in which Sivan recompiles the original to focus on close-ups of the perpetrator. This maneuver dis-allows a habitual spectatorial identification with the Jewish witnesses testifying before the court and recalls Hannah Arendt's Eichmann in Jerusalem: A Report on the Banality of Evil (New York: Penguin, 1963). As such it is presumably meant to incite the viewer to take a polemical position rather than merely remain passive. Chapter 7, "The Erasure of the Trace: The Restoration of Meaning/Artur Żmijewski: 
Portuges, Catherine. "Kékesi, Zoltán. 2015. Agents of Liberation - Holocaust Memory in Contemporary Art and Documentary Film. Trans. Reuben Fowlkes. Budapest and New York: Central European University Press; Saint Helena, CA: Helena History Press. 221 pages." Hungarian Cultural Studies. e-Journal of the American Hungarian Educators Association, Volume 11 (2018) DOI: 10.5195/ahea.2018.342

80064 (2004)," foregrounds a transgressive short film in which Polish artist Żmijewski persuades ninety-two year-old Holocaust survivor Józef Tarnawa to have his Auschwitz number retattooed on his arm while on camera; Kékesi writes that the Polish artist "thus produces a feeling of solidarity [with the victim] that is based on a form of rejection of the film"(148). This scenario recalls the moment in Shoah when Lanzmann insists that Auschwitz survivor and former barber Abraham Bomba recall in his own words for the camera the traumatic experience of being forced to cut the hair of victims destined for the gas chamber.

Chapter 8, "Trauma and Simulacra/Omer Fast: Spielberg's List (2003)," ponders the question of cultural appropriation of trauma through a series of interviews with Poles from the region of Kraków who served as extras in the production of Schindler's List (1993), only a few years after the collapse of the socialist regime. The confluence and tension between past and present stages a site of reflection that enables Kékesi to complicate commonly held ideas about genocide. Chapter 9, "From the Culture of Grief to the Politics of Imagination/Yael Bartana: Polish Trilogy (2007-2011)," is based on a speech held by Władysław Gomułka, First Secretary of the United Polish Workers Party, at the Warsaw Congress of the Workers Trade Union on June $19^{\text {th }}, 1967$, in which he spoke of the country's Jews as a "fifth column." Finally, Clemens von Wedemeyer's three-channel video installation Rushes, discussed in Chapter 10, "Agents of Liberation," re-situates the deportees to the Breitenau concentration camp, once a monastery in Germany and in the early 1930s Nazi era a workhouse for "asocial elements," at the moment of the camp liberation.

Although the absence of an integrative conclusion places the task of synthesis on the reader, the author contends persuasively that paradigms and concepts of Holocaust memory have in fact shifted significantly from the era in which survivor testimony and trauma were the dominant tropes, beginning in the aftermath of the war, when recordings of survivor accounts were first made. The identity of survivor and witness began to emerge as a result of the Eichmann trial of 1961 and of psychological research into the sequelae of trauma, as practices of remembrance and "memorial culture" developed in the West in the late 1970s and 1980s and valorized public accounts of personal experience.

Relying on the words of historical actors, the "era of the witness" that dominated Holocaust discourse during the 1980s corresponds to the history of production of Shoah, beginning in 1974 and ending in its release in 1985. Indeed, the author's comparative analysis of Jewish resistance in the two films made by Lanzmann, in Chapters 1 and 2, figures the reappropriation of violence in the second film as subverting the sense of powerlessness conveyed in Shoah, the first. Annette Wierworka's L'Ère du témoin/The Era of the Witness (Paris: Plon, 1998; Eng. trans. by Jared Stark; Ithaca, NY: Cornell UP, 2006) is referenced as a foundational text for this discussion. Debates on genocide at that time focalized primarily on the ethical limits of visual representation (e.g., Lanzmann's proscription: "The Shoah cannot be shown"), and on concerns regarding the deleterious effects of retraumatization on victims/survivors enacted through these modalities, as evidenced in the psychoanalytic perspectives of Shoshana Felman and Dori Laub.

By the turn of the twenty-first century, the "era of the witness" had begun to be overtaken by other esthetic and moral imperatives: marked by the publication of Didi-Huberman's Images malgré tout in 2004, the use of archives became a hallmark of contemporary art, inaugurating a 
Portuges, Catherine. "Kékesi, Zoltán. 2015. Agents of Liberation - Holocaust Memory in Contemporary Art and Documentary Film. Trans. Reuben Fowlkes. Budapest and New York: Central European University Press; Saint Helena, CA: Helena History Press. 221 pages." Hungarian Cultural Studies. e-Journal of the American Hungarian Educators Association, Volume 11 (2018) DOI: 10.5195/ahea.2018.342

new stage in the intergenerational transmission of Holocaust memory. Paradoxically, Kékesi's case studies were, for the most part, undertaken during the "witness era" and are primarily drawn from Central-European spaces, in some measure due to his own Hungarian background, a fact that also motivates his political positioning with regard to the rise of racism and xenophobia in Hungary and beyond. For as much as the book as a whole concerns the circulation of Holocaust memory in public space, the reader may be surprised to learn that little attention is paid in this otherwise impressive volume to the reception of the case studies examined here, particularly with regard to Jewish memory.

In what ways, then, one might ask, could Kékesi's theoretical and methodological approach be applicable to work from other regions, countries and cultures? One might think, for example, of the Hungarian director László Nemes's fiction feature, Son of Saul (2015)—a work that Lanzmann called the "anti-Schindler's List" and that prompted Didi-Huberman to publish a book-form letter to the director - and of the Sonderkommando protagonist's obsessive determination to act malgré tout to arrange a proper burial for a dead boy gassed in Auschwitz and sent on to be cremated, whom he calls his "son." Questions that have been posed innumerable times continue to be debated in the scholarly discourse of the Holocaust, as this volume demonstrates: what esthetic forms are amenable to the memory of the Shoah? should narrative fiction or hybrid forms be made, and, if so, how? and to what extent do contemporary artists favor strategies that promote agency over representation? Persuasively elaborating the concern of contemporary artists and filmmakers to mobilize an interactive approach that engages with the present, Zoltán Kékesi's major study makes a vibrant, provocative and necessary contribution to the literature on Holocaust memory, representation and transmission. 